\title{
Sources and Processes Contributing to Nitrogen Deposition: An Adjoint Model Analysis Applied to Biodiversity Hotspots Worldwide
}

\author{
Fabien Paulot, ${ }^{* \dagger}$ Daniel J. Jacob, ${ }^{\dagger}$ and Daven K. Henze \\ ${ }^{\dagger}$ School of Engineering and Applied Sciences, Harvard University, Cambridge, Massachusetts 02138, United States \\ ${ }^{\ddagger}$ Department of Mechanical Engineering, University of Colorado, Boulder, Colorado 80309, United States
}

\section{Supporting Information}

ABSTRACT: Anthropogenic enrichment of reactive nitrogen $(\mathrm{Nr})$ deposition is an ecological concern. We use the adjoint of a global 3-D chemical transport model (GEOS-Chem) to identify the sources and processes that control $\mathrm{Nr}$ deposition to an ensemble of biodiversity hotspots worldwide and two U.S. national parks (Cuyahoga and Rocky Mountain). We find that anthropogenic sources dominate deposition at all continental sites and are mainly regional (less than 1000 $\mathrm{km}$ ) in origin. In Hawaii, $\mathrm{Nr}$ supply is controlled by oceanic emissions of ammonia (50\%) and anthropogenic sources

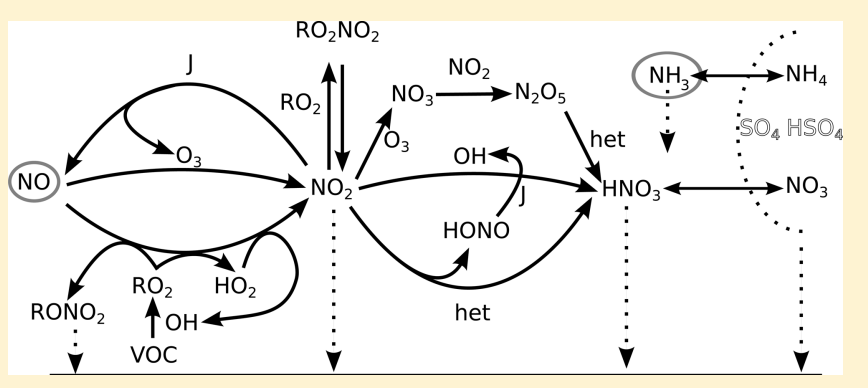
(50\%), with important contributions from Asia and North America. $\mathrm{Nr}$ deposition is also sensitive in complicated ways to emissions of $\mathrm{SO}_{2}$, which affect $\mathrm{Nr}$ gas-aerosol partitioning, and of volatile organic compounds (VOCs), which affect oxidant concentrations and produce organic nitrate reservoirs. For example, VOC emissions generally inhibit deposition of locally emitted $\mathrm{NO}_{x}$ but significantly increase $\mathrm{Nr}$ deposition downwind. However, in polluted boreal regions, anthropogenic VOC emissions can promote $\mathrm{Nr}$ deposition in winter. Uncertainties in chemical rate constants for $\mathrm{OH}+\mathrm{NO}_{2}$ and $\mathrm{NO}_{2}$ hydrolysis also complicate the determination of source-receptor relationships for polluted sites in winter. Application of our adjoint sensitivities to the representative concentration pathways (RCPs) scenarios for 20102050 indicates that future decreases in $\mathrm{Nr}$ deposition due to $\mathrm{NO}_{x}$ emission controls will be offset by concurrent increases in ammonia emissions from agriculture.

\section{INTRODUCTION}

Reactive nitrogen $(\mathrm{Nr})$ deposition has more than tripled since preindustrial times primarily due to $\mathrm{Nr}$ production and release from the agriculture and energy sectors. ${ }^{1}$ Because $\mathrm{Nr}$ is a limiting nutrient in many ecosystems, this increase in $\mathrm{Nr}$ deposition has been associated with greater net primary productivity $^{2-4}$ but also with threats to biodiversity ${ }^{5}$ through pathogens, ${ }^{6}$ eutrophication, ${ }^{7}$ and loss of species adapted to low $\mathrm{Nr}$ availability. ${ }^{8}$

Anthropogenic $\mathrm{Nr}$ is released to the atmosphere either as nitrogen oxides $\left(\mathrm{NO}_{x} \equiv \mathrm{NO}+\mathrm{NO}_{2}\right)$, mainly from combustion, or as ammonia $\left(\mathrm{NH}_{3}\right)$, mainly from agriculture. $\mathrm{NO}_{x}$ is oxidized in the atmosphere to nitric acid $\left(\mathrm{HNO}_{3}\right)$, which is rapidly deposited, and to organic nitrates including peroxyacetylnitrate (PAN), which can serve as reservoirs of $\mathrm{Nr}$ and facilitate its long-range transport. ${ }^{9,10} \mathrm{NH}_{3}$ is removed efficiently by wet and dry deposition. $\mathrm{NH}_{3}$ also partitions into aerosols as ammonium sulfate and ammonium nitrate, which makes it more resistant to dry deposition. In this manner, the long-range transport and deposition of $\mathrm{Nr}$ is coupled by atmospheric chemistry to other emissions including volatile organic compounds (VOCs) and sulfur dioxide $\left(\mathrm{SO}_{2}\right)$.

The observation network for $\mathrm{Nr}$ deposition is sparse and incomplete (e.g, dry deposition is generally not measured). Therefore estimates of $\mathrm{Nr}$ deposition generally rely on chemical transport models (CTMs), which relate sources to deposition through atmospheric transport and chemistry and can be evaluated with available observations. ${ }^{11,12}$ The processes controlling $\mathrm{Nr}$ deposition at a particular receptor site can in principle be fully characterized by perturbing successive source regions, source types, and other processes in the CTM. ${ }^{12,13}$ However, this approach is in practice severely limited by the computational expense of conducting a large number of CTM simulations.

The adjoint of a CTM allows the sources and processes controlling $\mathrm{Nr}$ deposition at a given receptor site to be characterized more efficiently. Through a single adjoint simulation, we can calculate the model sensitivity of $\mathrm{Nr}$ deposition at a particular location to a very large number of model variables for a cost comparable to that of a few forward simulations. ${ }^{14,15}$ This technique has been applied previously to characterize source-receptor relationships for $\mathrm{NO}_{x}{ }^{16}$ ozone, ${ }^{17-21}$ and black carbon. ${ }^{22}$

Here we use the adjoint of the GEOS-Chem global CTM to determine the sources and other processes contributing to $\mathrm{Nr}$

Received: July 10, 2012

Revised: $\quad$ March 3, 2013

Accepted: March 4, 2013

Published: March 4, 2013 


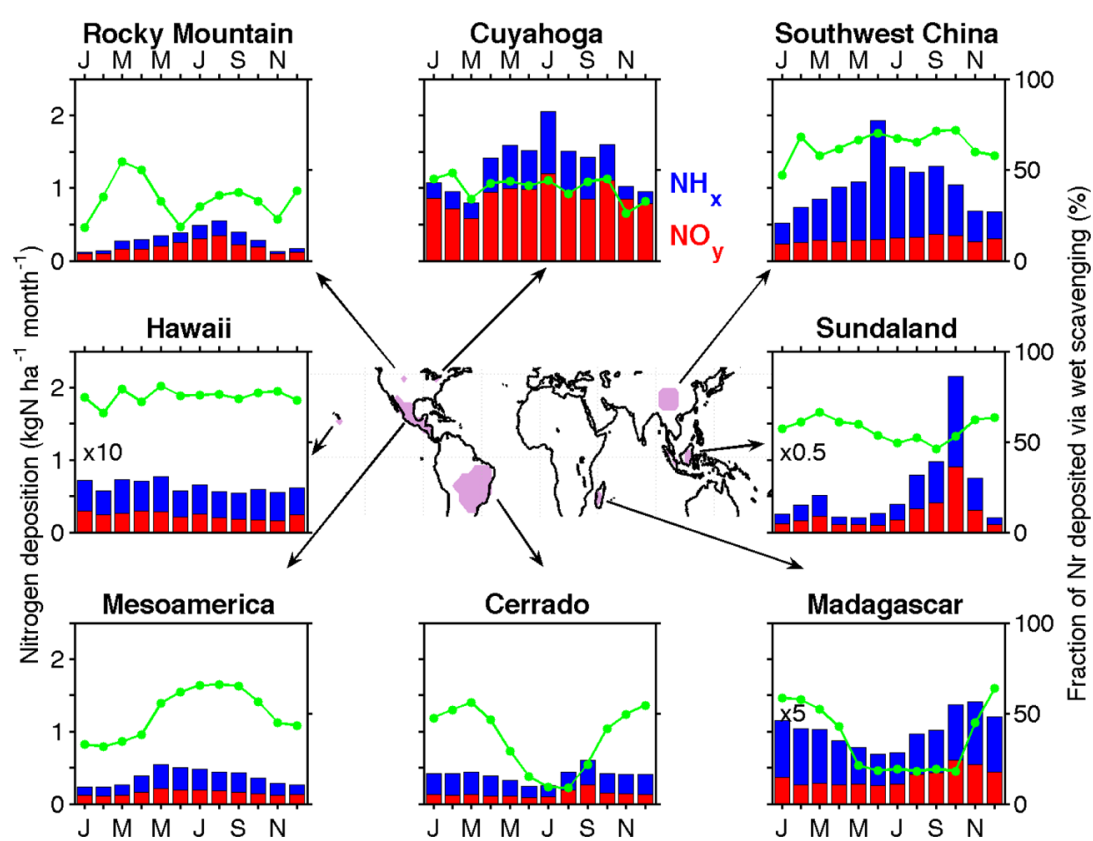

Figure 1. Reactive nitrogen ( $\mathrm{Nr}$ ) deposition in selected biodiversity hotspots and U.S. National Parks (purple) as simulated by GEOS-Chem for 2006. Monthly mean deposition fluxes are shown for reactive nitrogen oxides $\left(\mathrm{NO}_{y}\right.$ in red) and reduced nitrogen $\left(\mathrm{NH}_{x}\right.$ in blue). $\mathrm{The}$ fraction of $\mathrm{Nr}$ removed via wet deposition is shown in green. For Hawaii, Madagascar, and Sundaland, the monthly Nr deposition fluxes have been multiplied by the indicated factor in order to fit on the common scale.

deposition to an ensemble of "biodiversity hotspots" around the world (Figure 1). Biodiversity hotspots are regions that exhibit exceptional richness in flora and fauna but are undergoing major loss of habitat. ${ }^{23,24}$ Elevated $\mathrm{Nr}$ deposition in these hotspots is of concern. ${ }^{25}$ We focus on a representative global subset of biodiversity hotspots: Cerrado (Brazil, 2000000 $\left.\mathrm{km}^{2}\right)$, Madagascar $\left(600000 \mathrm{~km}^{2}\right)$, Mesoamerica (central America, $1100000 \mathrm{~km}^{2}$ ), Volcanoes National Park in Hawaii $\left(1300 \mathrm{~km}^{2}\right)$, Southwest China $\left(260000 \mathrm{~km}^{2}\right)$, and Sundaland (Malaysia and Indonesia, $1500000 \mathrm{~km}^{2}$ ). We also consider two U.S. National Parks, Cuyahoga in Ohio $\left(130 \mathrm{~km}^{2}\right)$ and Rocky Mountain in Colorado $\left(1100 \mathrm{~km}^{2}\right)$, where elevated $\mathrm{Nr}$ deposition is of concern. ${ }^{26}$ Cuyahoga is located in the vicinity of large anthropogenic sources of Nr, while Rocky Mountain is more remote but highly sensitive to $\mathrm{Nr}$ deposition enrichments. $^{27,28}$

\section{METHOD}

We use the adjoint of the GEOS-Chem CTM, a community open-source model v8.2.1 (www.geos-chem.org ${ }^{29}$ ). We focus our analysis on 2006, for which Zhang et al. ${ }^{12}$ previously reported a detailed analysis of GEOS-Chem $\mathrm{Nr}$ deposition in North America including extensive comparison to observations. GEOS-Chem is driven by GEOS-5 assimilated meteorological data from the NASA Goddard Earth Observing System with horizontal resolution of $0.5^{\circ} \times 0.67^{\circ}$ and 72 vertical levels. We degrade the horizontal resolution to $4^{\circ} \times 5^{\circ}$ for use in GEOSChem. Anthropogenic emissions of $\mathrm{NO}_{x}$ and $\mathrm{SO}_{2}$ are from the EDGAR inventory ${ }^{30}$ and $\mathrm{NH}_{3}$ emissions are from the GEIA inventory. ${ }^{31}$ These global inventories are superseded by regional inventories for the U.S. (EPA NEI05), Europe $\left(\mathrm{EMEP}^{32}\right)$, East Asia, ${ }^{33}$ Canada $\left(\mathrm{CAC}^{34}\right)$, and Mexico $\left(\mathrm{BRAVO}^{35}\right) \cdot \mathrm{NO}_{x}$ is also emitted from biomass burning $\left(\mathrm{GFED} 2^{36}\right)$, soil, ${ }^{37,38}$ and lightning. ${ }^{39}$ Anthropogenic emissions of $\mathrm{NH}_{3}$ have seasonal variations in the U.S., ${ }^{12}$ Europe, ${ }^{40}$ and Asia. ${ }^{41}$ Natural emissions of $\mathrm{NH}_{3}$ follow the GEIA inventory and include emissions from soil, vegetation, and oceans. ${ }^{31}$ Table 1 summarizes the global emissions of $\mathrm{Nr}$ in the model. Biogenic VOC emissions are from MEGAN v2.0. ${ }^{42}$

Table 1. Global Sources of Reactive Nitrogen in GEOSChem (2006)

$\begin{array}{clc}\text { source type } & \mathrm{Tg} \mathrm{N} \mathrm{a} \\ \mathrm{NO}_{x} & \text { fuel combustion } & 27.8 \\ & \text { fossil fuel (surface) } & 25.7 \\ & \text { biofuel } & 1.6 \\ & \text { jet fuel } & 0.5 \\ & \text { soil } & 6.9 \\ & \text { open fires } & 5.1 \\ & \text { lightning } & 2.3 \\ & \text { fertilizer } & 0.6 \\ & \text { total } & 42.7 \\ \mathrm{NH}_{3} & \text { agriculture } & 36 \\ & \text { natural } & \\ & \text { open fires } & 14.3 \\ & \text { biofuel } & 5.3 \\ \text { total } & 1.6\end{array}$

${ }^{a}$ Ocean, soil, and excreta from wild animals.

Dry deposition is calculated using a standard resistance-inseries model ${ }^{38,43}$ applied to a surface-type database from Olson $^{44}$ that includes local information for the receptor regions of interest. Annual mean daytime dry deposition velocities in the contiguous U.S. in GEOS-Chem are $2.7 \mathrm{~cm} \mathrm{~s}^{-1}$ for gaseous $\mathrm{HNO}_{3}, 0.65 \mathrm{~cm} \mathrm{~s}^{-1}$ for $\mathrm{NH}_{3}$, and $0.15 \mathrm{~cm} \mathrm{~s}^{-1}$ for aerosol $\mathrm{NH}_{4}^{+}$ and $\mathrm{NO}_{3}{ }^{-12}$. Wet deposition is treated as described by Liu et $\mathrm{al}^{45}$ for aerosols and by Mari et al. ${ }^{46}$ for gases. Deposition is treated independently of emission, assuming that atmospheric and surface reservoirs are not locally coupled. Accounting for this local coupling with a surface reservoir linked to the atmospheric model $^{47}$ would extend the spatial range of 
influence of sources through the re-emission process (grasshopper effect).

The model chemistry of $\mathrm{NO}_{y} \equiv \mathrm{NO}_{x}+\mathrm{NO}_{3}+2 \mathrm{~N}_{2} \mathrm{O}_{5}+$ $\mathrm{HONO}+\mathrm{HO}_{2} \mathrm{NO}_{2}+$ organic nitrates is based on Horowitz et al. ${ }^{48}$ with updates summarized by Zhang et al. ${ }^{12}$ PAN, higher peroxyacylnitrates, and alkyl nitrates are treated explicitly. Following Paulot et al., ${ }^{20}$ we assume that isoprene nitrates are rapidly oxidized, behaving like a temporary $\mathrm{NO}_{x}$ reservoir rather than a sink. Formation of sulfate-nitrate-ammonium aerosol is simulated with the RPMARES thermodynamic equilibrium model. ${ }^{49}$ The model also includes heterogeneous uptake on aerosols of $\mathrm{N}_{2} \mathrm{O}_{5}\left(\mathrm{~N}_{2} \mathrm{O}_{5} \rightarrow 2 \mathrm{HNO}_{3}{ }^{50}\right), \mathrm{NO}_{2}\left(2 \mathrm{NO}_{2}\right.$ $\left.\rightarrow \mathrm{HONO}+\mathrm{HNO}_{3}, \gamma=10^{-4}\right)$, and $\mathrm{NO}_{3}\left(\mathrm{NO}_{3} \rightarrow \mathrm{HNO}_{3}, \gamma\right.$ $=10^{-351}$ ).

Table 2 compares the GEOS-Chem $\mathrm{Nr}$ deposition fluxes for the selected receptor regions to those from the TM3 $\mathrm{CTM}^{25}$

\section{Table 2. Annual Nr Deposition $\left(\mathrm{kg} \mathrm{N} \mathrm{ha}^{-1} \mathrm{a}^{-1}\right)$ in Receptor} Regions $^{a}$

\begin{tabular}{|c|c|c|c|}
\hline \multirow[b]{2}{*}{ receptor region } & \multicolumn{2}{|c|}{ models } & \multirow[b]{2}{*}{ observations } \\
\hline & $\begin{array}{l}\text { GEOS-Chem (this } \\
\text { work) }\end{array}$ & $\mathrm{TM}^{b}$ & \\
\hline \multicolumn{4}{|c|}{ Northern Hemisphere } \\
\hline Cuyahoga NP & 15.9 & & \\
\hline wet $\mathrm{NH}_{4}^{+}$ & 3.2 & & $3.2^{c}$ \\
\hline wet $\mathrm{NO}_{3}^{-}$ & 3.2 & & $2.8^{c}$ \\
\hline $\begin{array}{l}\text { Rocky Mountain } \\
\text { NP }\end{array}$ & 3.6 & & \\
\hline wet $\mathrm{NH}_{4}^{+}$ & 0.6 & & $1.0^{d}$ \\
\hline wet $\mathrm{NO}_{3}^{-}$ & 0.6 & & $1.1^{d}$ \\
\hline Mesoamerica & 4.4 & 4.5 & \\
\hline Southwest China & 12.3 & $10\left(10-20^{e}\right)$ & \\
\hline Hawaii & 0.8 & 0.5 & \\
\hline \multicolumn{4}{|c|}{ Southern Hemisphere } \\
\hline Cerrado & 4.8 & 6 & \\
\hline Madagascar & 2.4 & 2 & \\
\hline Sundaland & 14.2 & 4 & \\
\hline wet $\mathrm{NH}_{4}^{+}$ & 4.5 & & $1.5^{f}$ \\
\hline wet $\mathrm{NO}_{3}^{-}$ & 2.9 & & $1.4^{f}$ \\
\hline
\end{tabular}

${ }^{a}$ Global biodiversity hotspots and U.S. National Parks (Figure 1). Values are for 2006 except TM3 (mid 1990s). ${ }^{b}$ Phoenix et al. ${ }^{25}{ }^{c}$ Site OH71 of the National Atmospheric Deposition Program (NADP; https://nadp.isws.illinois.edu/). ${ }^{d}$ Site CO19 (NADP). ${ }^{e}$ From the regional model of Lü and Tian. ${ }^{57}{ }^{\text {Average of sites Danum Valley and }}$ Tanah Rata of the Acid Deposition Monitoring Network in East Asia (EANET; http://www.eanet.cc/product/index.html).

and to available observations. There is generally good agreement between model and observations. The model is a factor of 2 too low at Rocky Mountain National Park but that could reflect topography not resolved on the coarse model grid scale. A nested high-resolution version of GEOS-Chem shows no such bias. ${ }^{52}$ It is a factor of $2-3$ too high in Sundaland, which suggests an overestimate of the biomass burning source. More detailed evaluations of similar GEOS-Chem versions as used here (including the same emissions) are presented by Fisher et al. ${ }^{41}$ and Zhang et al. ${ }^{12}$ Zhang et al. ${ }^{12}$ conducted an extensive full-year 2006 comparison for North America with $\mathrm{NH}_{x}$ and $\mathrm{NO}_{y}$ atmospheric data and wet deposition fluxes. They found good agreement for wet deposition fluxes of $\mathrm{NO}_{3}{ }^{-}$ (annual normalized mean bias $(\mathrm{ANMB})=8 \%), \mathrm{NH}_{4}{ }^{+}(\mathrm{ANMB}$ $=1.2 \%)$, as well as for $\mathrm{HNO}_{3}(\mathrm{ANMB}=18 \%)$. CASTNeT calculations of $\mathrm{HNO}_{3}$ dry deposition rates ${ }^{53}$ are about twice lower than GEOS-Chem but do not account for the diurnal correlation between $\mathrm{HNO}_{3}$ concentration and dry deposition velocity and are thus likely biased low. Fisher et al. ${ }^{41}$ compared GEOS-Chem $\mathrm{NH}_{4}{ }^{+}$wet deposition fluxes to observations in Europe and East Asia in the spring of 2008 and found biases of less than $10 \%$.

Figure 1 shows the simulated $\mathrm{Nr}$ deposition at the different receptor sites considered here. $\mathrm{NH}_{x}$ is the dominant contributor except at continental U.S. sites. Total $\mathrm{Nr}$ deposition is highest at Cuyahoga and Southwest China, reflecting large anthropogenic sources, and at Sundaland, reflecting large fires in Indonesia during a moderate El Niño. ${ }^{54}$ Tropical sites show little seasonality (except for biomass burning) as dry deposition compensates for the low wet deposition during the dry season. Overall the wet contribution to total deposition is about $50 \%$. The contribution of wet deposition to $\mathrm{Nr}$ deposition shows a strong seasonal cycle at tropical sites (Madagascar, Cerrado, and Mesoamerica), with a well-defined minimum during the dry season (20\% in Cerrado). In Hawaii, wet deposition accounts for $\sim 80 \%$ of $\mathrm{Nr}$ deposition throughout the year.

The model adjoint provides a computationally efficient way to derive the sensitivity of a given model variable (here the $\mathrm{Nr}$ total deposition flux) to a large ensemble of model parameters (here emissions and reaction rate constants). Briefly, at every time step we can write $\mathbf{c}_{n}=F\left(\mathbf{c}_{n-1}\right)$, where $\mathbf{c}_{n}$ is a vector describing the concentration of the different chemical species simulated by the GEOS-Chem at time step $n$ and $F$ is the GEOS-Chem operator. If a response metric $J$ is a function of $\mathbf{c}_{n}$, such as total deposition flux, it can be shown using the chain rule that the gradient of $J$ with respect to the model parameters $p$ is given by $\nabla_{\mathbf{p}} J=\sum_{i=1}^{n}\left(\left(\partial \mathbf{c}_{i}\right) /(\partial \mathbf{p})\right)^{T} \nabla_{\mathbf{c}_{j}} J$ where $\nabla_{\mathbf{c}_{\mathrm{i}}} J=$ $\prod_{j=1}^{n-1}\left(\left(\partial \mathbf{c}_{j+1}\right) /\left(\partial \mathbf{c}_{j}\right)\right)^{T}\left((\partial J) /\left(\partial \mathbf{c}_{n}\right)\right)^{T}$. In the adjoint model this product is evaluated from right to left, by propagating model sensitivities backward in time. In this manner, the ensemble of model sensitivities of a model response to a large number of parameters $p$ can be obtained by a single execution of the adjoint model. The adjoint of GEOS-Chem has been described before $^{55}$ and applied previously to diagnose the sensitivity of model concentrations to sources. ${ }^{17,56}$ As part of this work, we constructed the adjoint component relating deposition flux to local concentrations $\left((\partial J) /\left(\partial \mathbf{c}_{n}\right)\right)^{T}$ in the above equation).

Adjoint simulations are conducted here for each receptor site of Figure 1 with $J$ defined as the total $\mathrm{Nr}$ deposition in the receptor site. We explore seasonal differences in the factors driving $\mathrm{Nr}$ deposition (Figure 1) by applying the adjoint analysis to the months of January and July 2006 for the northern hemisphere regions and to the months of April and October 2006 for the southern tropical regions. The receptor variable is the total $\mathrm{Nr}$ deposition to the region for that month and the model parameter sensitivity variables are the mean values for that month and the preceding month. We calculate the sensitivity of $\mathrm{Nr}$ deposition to the grid-resolved emissions of $\mathrm{NO}_{x}$ and $\mathrm{NH}_{3}$ from each source type as well as to non-Nr emissions (VOCs and $\mathrm{SO}_{2}$ ) and chemical rate constants. Similar to Paulot et al., ${ }^{20}$ we report the sensitivity of $J$ to processes occurring in the months under consideration and in that preceding it. In the interest of readability, we will refer to the sensitivity of $\mathrm{Nr}$ deposition to a specific $\mathrm{Nr}$ source as the "contribution" from that source. We find that the sum of adjoint sensitivities to $\mathrm{Nr}$ emissions closely matches total $\mathrm{Nr}$ deposition (Supporting Information, Figure S1), implying that the relationship between $\mathrm{Nr}$ sources and deposition is indeed 
close to linear. Greater nonlinearity is to be expected in the relationship of $\mathrm{Nr}$ deposition to non-Nr emissions. Our results are for a single year (2006). Previous work for North America shows little interannual variability of $\mathrm{Nr}$ deposition in GEOSChem, ${ }^{12}$ although larger variability would be expected in the tropics from biomass burning. In particular, 2006 biomass burning emissions in Southeast Asia (affecting Sundaland) were anomalously high. ${ }^{54}$

\section{RESULTS AND DISCUSSION}

Source Attribution. Figure 2 shows the spatial footprint of the anthropogenic $\mathrm{Nr}$ sources (fuel combustion and

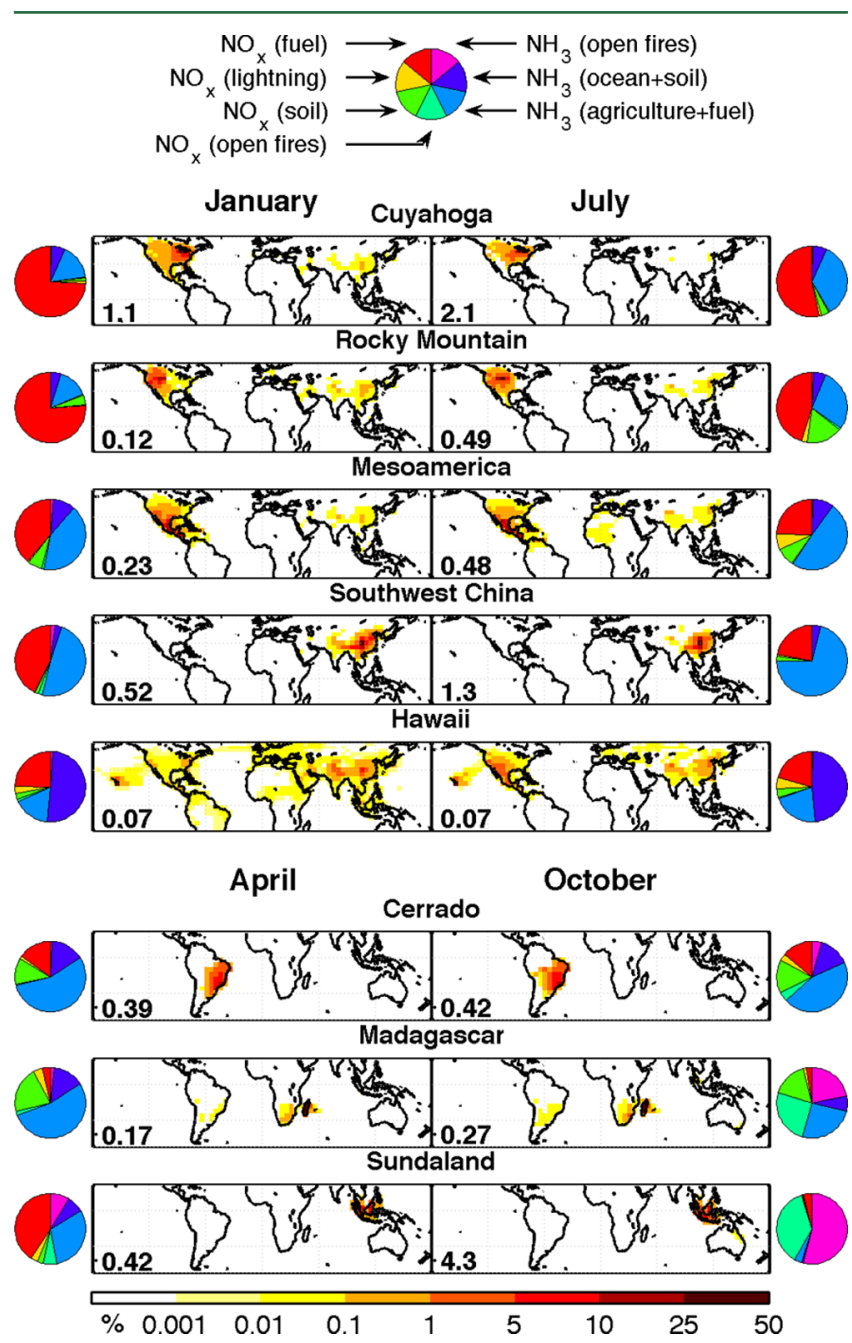

Figure 2. Source contributions to nitrogen deposition for the different receptor regions of Figure 1. The maps show the anthropogenic footprints as the fractional contribution of anthropogenic $\mathrm{Nr}$ emissions in each $4^{\circ} \times 5^{\circ}$ grid cell to the anthropogenic $\mathrm{Nr}$ deposition (in \%) in the receptor regions. The sum of all the contributions amounts to $99 \%$ of the anthropogenic component of $\mathrm{Nr}$ deposition. Pie charts indicate the relative contribution of different $\mathrm{Nr}$ source types to the total $\mathrm{Nr}$ deposition. The total monthly $\mathrm{Nr}$ deposition flux for the region (in $\mathrm{kg}$ $\mathrm{N} \mathrm{ha}{ }^{-1}$ month $^{-1}$ ) is shown in inset.

agriculture) contributing to $\mathrm{Nr}$ deposition (map) as well as the contribution from the different $\mathrm{Nr}$ sources (pie charts). The contribution of natural emissions to $\mathrm{Nr}$ deposition can be further separated into a local component, where $\mathrm{Nr}$ is simply recycled within the ecosystem, and an external component, where $\mathrm{Nr}$ is transferred between ecosystems or generated by lightning. For our purpose we define the local component as that originating from the same $4^{\circ} \times 5^{\circ}$ grid squares as the receptor region. Only in Hawaii and Sundaland are natural external $\mathrm{Nr}$ sources comparable to or greater than anthropogenic inputs. Soil $\mathrm{NO}_{x}$ generally provides $10 \%-25 \%$ of the external natural $\mathrm{Nr}$ input with maximum contribution in Rocky Mountain (50\%) and negligible contribution in Hawaii. Lightning $\mathrm{NO}_{x}$ provides over $50 \%$ of the external natural $\mathrm{Nr}$ input at tropical/subtropical sites but less than $10 \%$ at midlatitude sites. The biomass burning contribution is small except in Sundaland (90\%). In Hawaii, oceanic emissions of $\mathrm{NH}_{3}$ account for over $85 \%$ of the natural $\mathrm{Nr}$ input but this source is very uncertain. Considering that Hawaiian ecosystems can be Nr-limited, ${ }^{58}$ there is a need to better understand this oceanic source. In the following, we focus on the footprint of the anthropogenic perturbation to $\mathrm{Nr}$ deposition.

Anthropogenic contribution to $\mathrm{Nr}$ deposition ranges from $40 \%$ (Hawaii) to over $90 \%$ (Southwest China), highlighting the anthropogenic perturbation to the nitrogen cycle worldwide. Sundaland during the biomass burning season is an exception with anthropogenic sources accounting for less than $10 \%$ of $\mathrm{Nr}$ deposition. Most of the $\mathrm{Nr}$ deposition to the continental receptor regions originates from sources within that region or nearby ( $500 \mathrm{~km}$ footprint). The footprint extends further in winter at Cuyahoga and Rocky Mountain because of slower oxidation of $\mathrm{NO}_{x}$ to $\mathrm{HNO}_{3}$. The US account for $30-40 \%$ of the anthropogenic $\mathrm{NO}_{y}$ deposited in Mesoamerica, and India accounts for $7-13 \%$ of the anthropogenic $\mathrm{Nr}$ deposited in Southwest China.

Intercontinental transport makes little contribution to $\mathrm{Nr}$ deposition except at Hawaii, consistent with the previous model study by Sanderson et al. ${ }^{13}$ For example, Asian anthropogenic sources account for only $7 \%$ of $\mathrm{NH}_{x}$ deposition at Rocky Mountain and $3 \%$ at Cuyahoga. At Hawaii, however, transpacific transport accounts for $\sim 40 \%$ of the anthropogenic $\mathrm{Nr}$ deposition, with a marked seasonal shift between winter and summer sources that reflects changes in the position of the North Pacific anticyclone. ${ }^{59}$ In winter, sources are dominated by Asia with China and India contributing, respectively, 19\% and $10 \%$ of the anthropogenic Nr. In contrast, in summer, the U.S. and Mexico together contribute $\sim 30 \%$ of the anthropogenic $\mathrm{Nr}$ deposition.

Sensitivity to Non-Nr Sources. $\mathrm{SO}_{2}$ emissions affect the deposition of $\mathrm{Nr}$ through the formation of sulfate-nitrateammonium aerosol, changing the partitioning of $\mathrm{Nr}$ between the gas and particle phases. Figure 3 shows the sensitivity of $\mathrm{Nr}$ deposition to $\mathrm{SO}_{2}$ emissions (blue bars) relative to $\mathrm{NH}_{3}$ emission. The effect can be large, up to $30 \%$ at Cuyahoga in winter, and variable in sign. Greater $\mathrm{SO}_{2}$ emissions increase the fraction of $\mathrm{NH}_{x}$ in the particle phase as ammonium, which generally lengthens the $\mathrm{NH}_{x}$ lifetime as particles are more resistant to dry deposition. Thus sources of $\mathrm{SO}_{2}$ located outside of receptor regions generally increase $\mathrm{Nr}$ deposition in these regions (e.g., $\mathrm{SO}_{2}$ sources in the U.S. for summertime Mesoamerica), while $\mathrm{SO}_{2}$ emissions located within the receptor region tend to favor $\mathrm{Nr}$ export (e.g., wintertime Mesoamerica). However, increasing $\mathrm{SO}_{2}$ emissions can also promote the volatilization of nitrate, particularly in winter, and hence increase its local deposition as $\mathrm{HNO}_{3}$ as gaseous $\mathrm{HNO}_{3}$ deposits faster than particulate nitrate. ${ }^{12}$ This explains the large positive sensitivity at Cuyahoga during that season.

Figure 3 also shows the response of $\mathrm{Nr}$ deposition to increasing emissions of anthropogenic VOCs (AVOCs, red) 


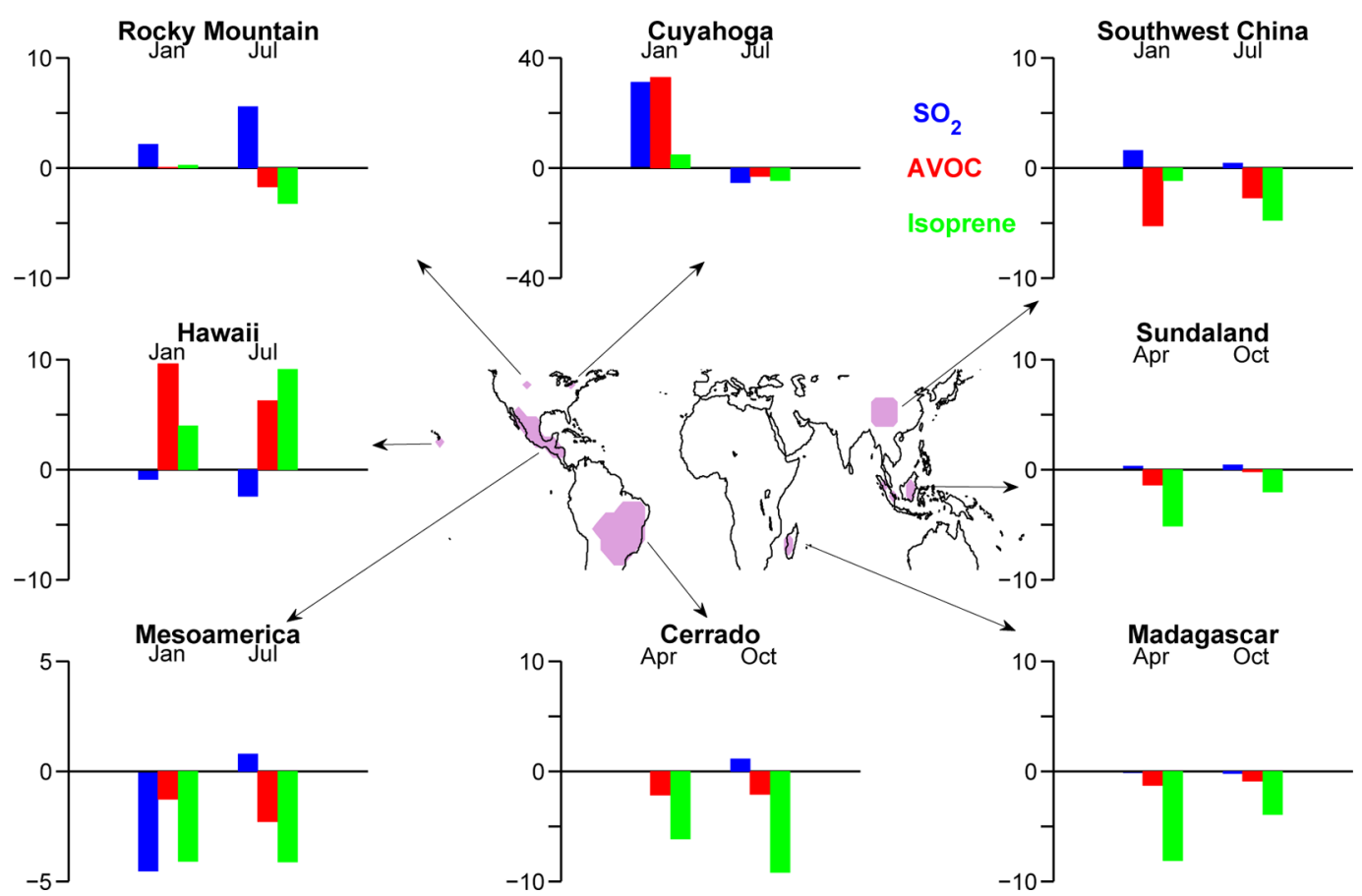

Figure 3. Sensitivity of $\mathrm{Nr}$ deposition to global non-Nr emissions, expressed as percentages of the sensitivity to $\mathrm{NH}_{3}$ emissions $\left(\right.$ for $\left.\mathrm{SO}_{2}(\mathrm{blue})\right)$ and of the sensitivity to $\mathrm{NO}_{x}$ emissions (for anthropogenic VOCs (AVOCs, red) and isoprene (green)) in January/April and July/October at northern/ southern hemisphere sites. Note the difference in scales among panels.

and biogenic isoprene (green). VOCs affect $\mathrm{Nr}$ deposition by changing $\mathrm{OH}$ and ozone concentrations (thus changing the lifetime of $\mathrm{NO}_{x}$ against oxidation to $\mathrm{HNO}_{3}$ ) and by converting $\mathrm{NO}_{x}$ to organic nitrates that do not deposit as readily as $\mathrm{HNO}_{3}$. The transport of these organic nitrates and the subsequent release of $\mathrm{NO}_{x}$ far from its point of origin ${ }^{9}$ causes the positive response of $\mathrm{Nr}$ deposition in Hawaii to global VOC emissions. In contrast, in low- $\mathrm{NO}_{x}$ regions such as Cerrado, $\mathrm{OH}$ depletion by isoprene photooxidation slows down the oxidation of $\mathrm{NO}_{x}$ to nitric acid and enables the conversion of a large fraction of $\mathrm{NO}_{x}$ to isoprene nitrates, ${ }^{20}$ causing a large negative sensitivity of $\mathrm{Nr}$ deposition to isoprene emission.

We see from the above discussion that the sensitivity of $\mathrm{Nr}$ deposition to $\mathrm{SO}_{2}$ or VOC emissions can change sign depending on the chemical environment and the distance of these emissions from the receptor region. Thus, the spatially integrated sensitivities shown in Figure 3 often reflect some cancellation between positive and negative regional dependences. This is illustrated in Figure 4 with the sensitivity of $\mathrm{NO}_{y}$ deposition to spatially resolved isoprene emissions at Cuyahoga (circle) in summer. Emissions of isoprene in the Northeast U.S., close to Cuyahoga, inhibit $\mathrm{NO}_{y}$ deposition while large upwind emissions in the U.S. Southeast increase it.

The large positive sensitivity of $\mathrm{NO}_{y}$ deposition to AVOC emissions at Cuyahoga in winter (Figure 3) reflects the importance of AVOCs in driving ozone production under $\mathrm{NO}_{x}$ saturated conditions, ${ }^{60}$ in turn promoting $\mathrm{NO}_{3}$ formation from the reaction of $\mathrm{NO}_{2}$ with ozone. This favors the production of $\mathrm{N}_{2} \mathrm{O}_{5}$, hydrolysis of which is the primary source of $\mathrm{HNO}_{3}$ in winter midlatitudes. ${ }^{61}$ Such polluted wintertime conditions also cause $\mathrm{Nr}$ deposition to depend on chemical rate constants in nonobvious ways. The sensitivity to the $\mathrm{N}_{2} \mathrm{O}_{5}$ reactive uptake probability $\left(\gamma_{\mathrm{N}_{2} \mathrm{O}_{5}}\right)$ is small $\left(<1 \%\right.$ of the sensitivity to $\mathrm{NO}_{x}$ emissions) because its formation is limited by $\mathrm{NO}_{3}$. We find that a decrease in the reaction rate coefficient for $\mathrm{OH}+\mathrm{NO}_{2}{ }^{62}$

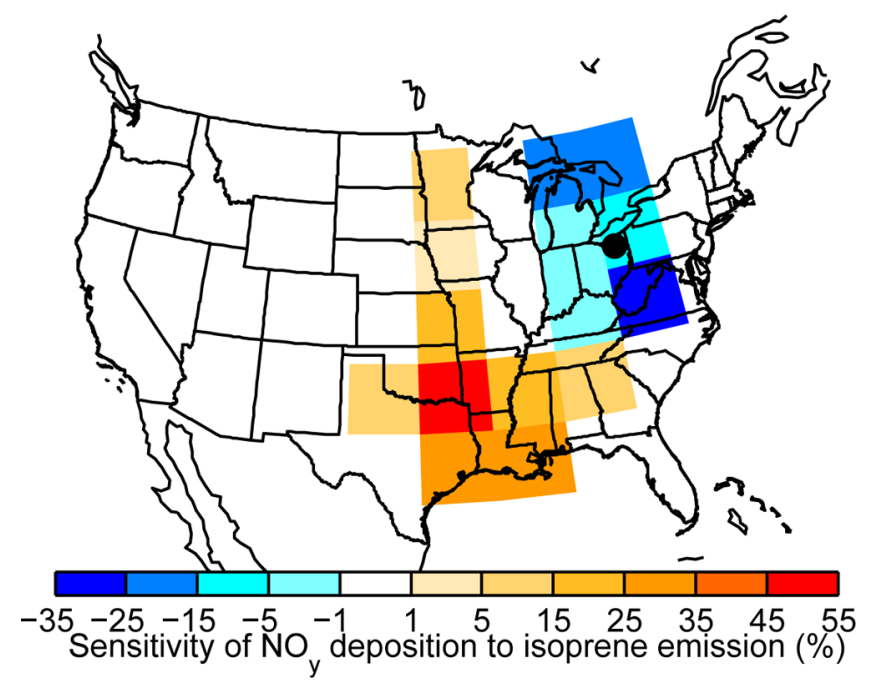

Figure 4. Sensitivity of $\mathrm{NO}_{y}$ deposition in July at Cuyahoga National Park (black circle) to spatially resolved isoprene emissions. The gridresolved sensitivity to isoprene emissions is divided by the sensitivity to collocated $\mathrm{NO}_{x}$ emissions. The sum of the absolute individual sensitivities shown here amounts to $90 \%$ of the overall absolute sensitivity of $\mathrm{Nr}$ deposition to isoprene emissions (see Figure 3).

would increase $\mathrm{Nr}$ deposition ( $\sim-45 \%$ of the sensitivity to $\mathrm{NO}_{x}$ emissions). Though $\mathrm{OH}+\mathrm{NO}_{2}$ is a source of nitric acid, it is also a sink of hydrogen oxide radicals $\left(\mathrm{HO}_{x}\right)$ and thus limits ozone production. We also find a large positive sensitivity ( $\sim 40 \%$ of the sensitivity to $\mathrm{NO}_{x}$ emissions) to the reactive uptake probability of $\mathrm{NO}_{2}$ on aerosols $\left(2 \mathrm{NO}_{2} \rightarrow \mathrm{HONO}+\right.$ $\mathrm{HNO}_{3}$ ). The most important impact of this reaction on $\mathrm{Nr}$ deposition is indirect: it contributes $\sim 45 \%$ of $\mathrm{HO}_{x}$ production at Cuyahoga in the wintertime and thus promotes the production of $\mathrm{N}_{2} \mathrm{O}_{5}$. Recent laboratory studies ${ }^{63-66}$ suggest 


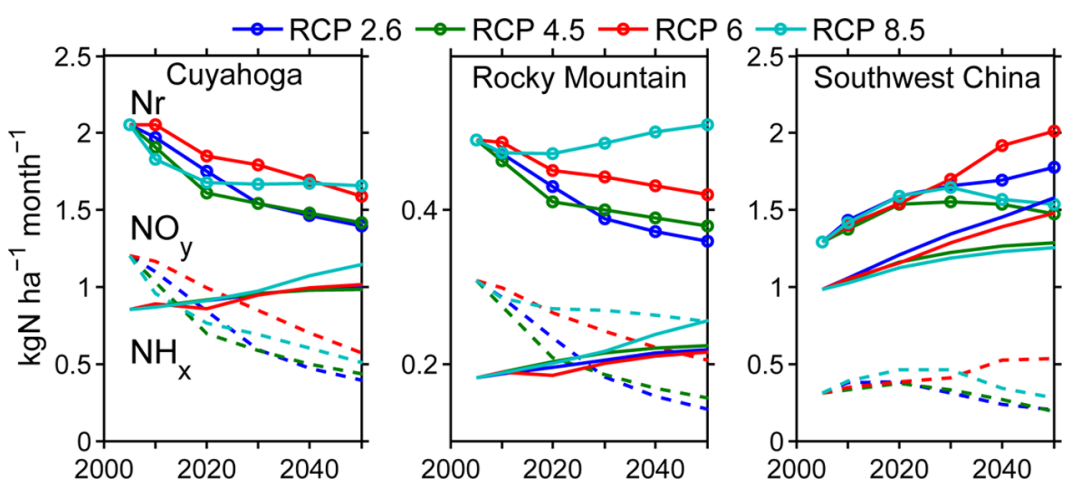

Figure 5. Future $\mathrm{Nr}$ deposition in July under the four Representative Concentration Pathways (RCP) scenarios ${ }^{69}$ adopted by the IPCC. For each scenario, the deposition of total $\mathrm{Nr}$ (solid line with circles), $\mathrm{NO}_{y}$ (dash line), and $\mathrm{NH}_{x}$ (solid line) are calculated by multiplying gridded changes in $\mathrm{Nr}$ emissions by the corresponding adjoint sensitivities.

that the $\mathrm{NO}_{2}$ reactive uptake probability of $10^{-4}$ used in GEOSChem may be more than 1 order of magnitude too high. Uncertainty in the wintertime sources of $\mathrm{HONO}^{67}$ could contribute to the overestimate of nitrate deposition and concentration in GEOS-Chem. $^{12,68}$

Future Projections. The Intergovernmental Panel on Climate Change (IPCC) has recently adopted four global gridded emission projections for the 21st century as Representative Concentration Pathways (RCPs) designed to achieve a certain radiative forcing cap by $2100 .{ }^{69}$ The RCP scenarios are defined by the magnitude of this cap (for example, RCP2.6 assumes a cap of $2.6 \mathrm{~W} \mathrm{~m}^{-2}$ ). In these scenarios, future $\mathrm{NO}_{x}$ emissions decrease in response to stringent emission controls in the U.S. and Europe, ${ }^{70,71}$ while $\mathrm{NH}_{3}$ emissions continue to increase because of the world's growing demand for food (Supporting Information, Figure S1). The sourcereceptor relationships calculated from the adjoint model allow us to readily estimate the response of $\mathrm{Nr}$ deposition to these or other emission projections, assuming that the response is linear and time-invariant and that the meteorology does not change. We find in our work that the sum of adjoint sensitivities to $\mathrm{Nr}$ emissions closely matches total $\mathrm{Nr}$ deposition (Supporting Information, Table S1), implying that the relationship between $\mathrm{Nr}$ sources and deposition is indeed close to linear.

Figure 5 shows the projected changes in $\mathrm{Nr}$ deposition out to 2050 for Cuyahoga, Rocky Mountain, and Southwest China for the four RCP scenarios. Nr deposition in Southwest China is expected to increase by $\sim 20 \%$ in the next decade in all scenarios. In the 2020s, $\mathrm{Nr}$ deposition decreases in the RCP4.5 and RCP8.5 scenarios reflecting the widespread adoption of air pollution regulations. However, in the RCP6 scenario, delayed regulation of industrial emissions results in an increase of $\mathrm{Nr}$ deposition by $\sim 75 \%$ by 2050 . $\mathrm{Nr}$ deposition is expected to decrease at the U.S. sites except in the RCP8.5 scenario, consistent with the results of Lamarque et al. ${ }^{72}$ due to lower $\mathrm{NO}_{x}$ emissions. By 2030, in all scenarios, $\mathrm{NH}_{x}$ is predicted to be the largest contributor to $\mathrm{Nr}$ deposition at Cuyahoga. As a result, $\mathrm{Nr}$ deposition improves much less after 2025. At the Rocky Mountain site, increasing $\mathrm{NH}_{3}$ emissions result in increasing $\mathrm{Nr}$ deposition in the RCP8.5 scenario. For both national parks, $\mathrm{Nr}$ deposition will continue to exceed the ecoregion critical load (3-8 $\mathrm{kg} \mathrm{N} \mathrm{ha}^{-1} \mathrm{a}^{-1}$ at Cuyahoga ; $3 \mathrm{~kg}$ $\mathrm{N} \mathrm{ha}^{-1} \mathrm{a}^{-1}$ at Rocky Mountain ${ }^{73}$ ) in the coming decades. Decrease of agricultural $\mathrm{NH}_{3}$ emissions will become necessary after 2020 to significantly diminish $\mathrm{Nr}$ deposition.

\section{ASSOCIATED CONTENT}

Supporting Information

Evaluation of the linearity of $\mathrm{Nr}$ deposition and trends in RCP emissions of $\mathrm{NO}, \mathrm{NH}_{3}$, and $\mathrm{Nr}$ in the U.S. and China. This material is available free of charge via the Internet at http:// pubs.acs.org.

\section{AUTHOR INFORMATION}

\section{Corresponding Author}

*E-mail: paulot@seas.harvard.edu.

\section{Notes}

The authors declare no competing financial interest.

\section{ACKNOWLEDGMENTS}

This study was funded by the NASA Applied Sciences Program. F.P. acknowledges support from the Harvard University Center for the Environment (HUCE). D.K.H. is supported by NASA ACMAP NNX10AG63G and EPA STAR RD83455901. F.P. thanks Raluca Ellis and Lin Zhang for helpful discussions.

\section{REFERENCES}

(1) Galloway, J. N.; Dentener, F. J.; Capone, D. G.; Boyer, E. W.; Howarth, R. W.; Seitzinger, S. P.; Asner, G. P.; Cleveland, C. C.; Green, P. A.; Holland, E. A.; Karl, D. M.; Michaels, A. F.; Porter, J. H.; Townsend, A. R.; Vöosmarty, C. J. Nitrogen cycles: past, present, and future. Biogeochemistry 2004, 70, 153-226.

(2) Magnani, F.; et al. The human footprint in the carbon cycle of temperate and boreal forests. Nature 2007, 447, 849-851.

(3) Pregitzer, K. S.; Burton, A. J.; Zak, D. R.; Talhelm, A. F. Simulated chronic nitrogen deposition increases carbon storage in Northern Temperate forests. Global Change Biol. 2008, 14, 142-153.

(4) Reay, D. S.; Dentener, F.; Smith, P.; Grace, J.; Feely, R. A. Global nitrogen deposition and carbon sinks. Nat. Geosci. 2008, 1, 430-437.

(5) Sala, O. E.; et al. Global Biodiversity Scenarios for the Year 2100. Science 2000, 287, 1770-1774.

(6) Johnson, P. T. J.; Townsend, A. R.; Cleveland, C. C.; Glibert, P. M.; Howarth, R. W.; McKenzie, V. J.; Rejmankova, E.; Ward, M. H. Linking environmental nutrient enrichment and disease emergence in humans and wildlife. Ecol. Appl. 2010, 20, 16-29.

(7) Bergström, A.-K.; Jansoon, M. Atmospheric nitrogen deposition has caused nitrogen enrichment and eutrophication of lakes in the northern hemisphere. Global Change Biol. 2006, 12, 635-643.

(8) Bobbink, R; i et al. Global assessment of nitrogen deposition effects on terrestrial plant diversity: A synthesis. Ecol. Appl. 2010, 20, $30-59$.

(9) Moxim, W. J.; Levy, I., H.; Kasibhatla, P. S. Simulated global tropospheric PAN: Its transport and impact on $\mathrm{NO}_{x}$. J. Geophys. Res. 1996, 101, 12621-12638. 
(10) Atherton, C. S. Organic nitrates in remote marine environments: Evidence for long range transport. Geophys. Res. Lett. 1989, 16, 1289-1292.

(11) Dentener, F.; et al. Nitrogen and sulfur deposition on regional and global scales: A multimodel evaluation. Global Biogeochem. Cycles 2006, 20, B4003.

(12) Zhang, L.; Jacob, D. J.; Knipping, E. M.; Kumar, N.; Munger, J. W.; Carouge, C. C.; van Donkelaar, A.; Wang, Y. X.; Chen, D. Nitrogen deposition to the United States: Distribution, sources, and processes. Atmos. Chem. Phys. 2012, 12, 4539-4554.

(13) Sanderson, M. G.; et al. A multi-model study of the hemispheric transport and deposition of oxidised nitrogen. Geophys. Res. Lett. 2008, 35, L17815.

(14) Giering, R.; Kaminski, T. Recipes for adjoint code construction. ACM T. Math. Software 1998, 24, 437-474.

(15) Errico, R. M. What is an adjoint model? Bull. Am. Meteorol. Soc. 1997, 78, 2577-2591.

(16) Vukićević, T.; Hess, P. Analysis of tropospheric transport in the Pacific Basin using the adjoint technique. J. Geophys. Res. 2000, 105, 7213-7230.

(17) Zhang, L.; Jacob, D. J.; Kopacz, M.; Henze, D. K.; Singh, K.; Jaffe, D. A. Intercontinental source attribution of ozone pollution at western U.S. sites using an adjoint method. Geophys. Res. Lett. 2009, 36, L11810.

(18) Menut, L.; Vautard, R.; Beekmann, M.; Honoré, C. Sensitivity of photochemical pollution using the adjoint of a simplified chemistrytransport model. J. Geophys. Res. 2000, 105, 15379-15402.

(19) Vautard, R.; Beekmann, M.; Menut, L. Applications of adjoint modelling in atmospheric chemistry: Sensitivity and inverse modelling. Environ. Modell. Softw. 2000, 15, 703-709.

(20) Paulot, F.; Henze, D. K.; Wennberg, P. O. Impact of the isoprene photochemical cascade on tropical ozone. Atmos. Chem. Phys. 2012, 12, 1307-1325.

(21) Walker, T. W.; et al. Impacts of midlatitude precursor emissions and local photochemistry on ozone abundances in the Arctic. J. Geophys. Res. 2012, 117, D01305.

(22) Kopacz, M.; Mauzerall, D. L.; Wang, J.; Leibensperger, E. M.; Henze, D. K.; Singh, K. Origin and radiative forcing of black carbon transported to the Himalayas and Tibetan Plateau. Atmos. Chem. Phys. 2011, 11, 2837-2852.

(23) Myers, N.; Mittermeier, R. A.; Mittermeier, C. G.; da Fonseca, G. A. B.; Kent, J. Biodiversity hotspots for conservation priorities. Nature 2000, 403, 853-858.

(24) Conservation International. The Biodiversity Hotspots. http:// www.conservation.org/where/priority_areas/hotspots/Pages/ hotspots_main.aspx

(25) Phoenix, G. K.; Hicks, W. K.; Cinderby, S.; Kuylenstierna, J. C. I.; Stock, W. D.; Dentener, F. J.; Giller, K. E.; Austin, A. T.; Lefroy, R. D. B.; Gimeno, B. S.; Ashmore, M. R.; Ineson, P. Atmospheric nitrogen deposition in world biodiversity hotspots: The need for a greater global perspective in assessing $\mathrm{N}$ deposition impacts. Global Change Biol. 2006, 12, 470-476.

(26) Sullivan, T. J.; McDonnell, T. C.; McPherson, G. T.; Mackey, S. D.;Moore, D. Evaluation of the Sensitivity of Inventory and Monitoring National Parks to Nutrient Enrichment Effects from Atmospheric Nitrogen Deposition; Natural Resource Report NPS/NRPC/ARD/NRR-2011/ 313; U.S. National Park Service, 2011.

(27) Wolfe, A. P.; Van Gorp, A. C.; Baron, J. S. Recent ecological and biogeochemical changes in alpine lakes of Rocky Mountain National Park (Colorado, USA): A response to anthropogenic nitrogen deposition. Geobiology 2003, 1, 153-168.

(28) Baron, J. S.; Rueth, H. M.; Wolfe, A. M.; Nydick, K. R.; Allstott, E. J.; Minear, J. T.; Moraska, B. Ecosystem Responses to Nitrogen Deposition in the Colorado Front Range. Ecosystems 2000, 3, 352368, DOI: $10.1007 / \mathrm{s} 100210000032$.

(29) Bey, I.; Jacob, D. J.; Yantosca, R. M.; Logan, J. A.; Field, B. D.; Fiore, A. M.; Li, Q.; Liu, H. Y.; Mickley, L. J.; Schultz, M. G. Global modeling of tropospheric chemistry with assimilated meteorology -
Model description and evaluation. J. Geophys. Res. 2001, 106, 2307323095.

(30) Olivier, J. G. J.; Berdowski, J. J. M. Global emission sources and sinks. In The Climate System; Berdowski, J., GuicheritR., Heij, B. J., Eds.; A.A. Balkema Publishers/Swets \& Zeitlinger Publishers: Lisse, The Netherlands, 2001; pp 33-77

(31) Bouwman, A. F.; Lee, D. S.; Asman, W. A. H.; Dentener, F. J.; Van Der Hoek, K. W.; Olivier, J. G. J. A global high-resolution emission inventory for ammonia. Global Biogeochem. Cycles 1997, 11, 561-587.

(32) Vestreng, V.; Klein, H. Emission data reported to UNECE/EMEP: Quality assurance and trend analysis \& Presentation of WebDab; Norwegian Meteorological Institute, 2002.

(33) Streets, D. G.; Bond, T. C.; Carmichael, G. R.; Fernandes, S. D.; Fu, Q.; He, D.; Klimont, Z.; Nelson, S. M.; Tsai, N. Y.; Wang, M. Q.; Woo, J.; Yarber, K. F. An inventory of gaseous and primary aerosol emissions in Asia in the year 2000. J. Geophys. Res. 2003, 108, 8809.

(34) Environment Canada. National Pollutant Release Inventory. http://www.ec.gc.ca/pdb/cac/cachomee.cfm

(35) Kuhns, H.; Knipping, E.; Vukovich, J. Development of a United States-Mexico Emissions inventory for the big bend regional aerosol and visibility observational (BRAVO) study. J. Air Waste Manage. 2005, 55, 677-692.

(36) Randerson, J. T.; van der Werf, G. R.; Giglio, L.; Collatz, G. J.; Kasibhatla, P. S. Global Fire Emissions Database, Version 2 (GFEDv2); 2006.

(37) Yienger, J. J.; Levy, H. Empirical model of global soil-biogenic $\mathrm{NO}_{x}$ emissions. J. Geophys. Res. 1995, 100, 11447-11464.

(38) Wang, Y.; Jacob, D. J.; Logan, J. A. Global simulation of tropospheric $\mathrm{O}_{3}-\mathrm{NO}_{x}$-hydrocarbon chemistry 1 . Model formulation. J. Geophys. Res. 1998, 103, 10713-10726.

(39) Sauvage, B.; Martin, R. V.; van Donkelaar, A.; Liu, X.; Chance, K.; Jaeglé, L.; Palmer, P. I.; Wu, S.; Fu, T.-M. Remote sensed and in situ constraints on processes affecting tropical tropospheric ozone. Atmos. Chem. Phys. 2007, 7, 815-838.

(40) Friedrich, R.; Reis, S. In Emissions of Air Pollutants Measurements, Calculations and Uncertainties.; Friedrich, R., Reis, S., Eds.; Springer-Verlag, 2004.

(41) Fisher, J. A.; et al. Sources, distribution, and acidity of sulfateammonium aerosol in the Arctic in winter-spring. Atmos. Environ. 2011, 45, 7301-7318.

(42) Guenther, A.; Karl, T.; Harley, P.; Wiedinmyer, C.; Palmer, P. I.; Geron, C. Estimates of global terrestrial isoprene emissions using MEGAN (Model of Emissions of Gases and Aerosols from Nature). Atmos. Chem. Phys. 2006, 6, 3181-3210.

(43) Wesely, M. . L. Parameterization of surface resistances to gaseous dry deposition in regional-scale numerical models. Atmos. Environ. 1989, 23, 1293-1304.

(44) Olson, J. World Ecosystems (WE1.4): Digital raster data on a 10 minute geographic 1080 x 2160 grid; 1992.

(45) Liu, H.; Jacob, D. J.; Bey, I.; Yantosca, R. M. Constraints from ${ }^{210} \mathrm{~Pb}$ and ${ }^{7} \mathrm{Be}$ on wet deposition and transport in a global threedimensional chemical tracer model driven by assimilated meteorological fields. J. Geophys. Res. 2001, 106, 12109-12128.

(46) Mari, C.; Bechtold, P.; Jacob, D. Transport and scavenging of soluble gases in a deep convective cloud. J. Geophys. Res. 2000, 105, 22255-22268.

(47) Cooter, E. J.; Bash, J. O.; Walker, J. T.; Jones, M.; Robarge, W. Estimation of $\mathrm{NH}_{3}$ bi-directional flux from managed agricultural soils. Atmos. Environ. 2010, 44, 2107-2115.

(48) Horowitz, L. W.; Liang, J.; Gardner, G. M.; Jacob, D. J. Export of reactive nitrogen from North America during summertime Sensitivity to hydrocarbon chemistry. J. Geophys. Res. 1998, 103, 13451-13476.

(49) Binkowski, F. S.; Roselle, S. J. Models-3 Community Multiscale Air Quality (CMAQ) model aerosol component 1 . Model description. J. Geophys. Res. 2003, 108. 
(50) Evans, M. J.; Jacob, D. Impact of new laboratory studies of $\mathrm{N}_{2} \mathrm{O}_{5}$ hydrolysis on global model budgets of tropospheric nitrogen oxides, ozone, and OH. Geophys. Res. Lett. 2005, 32, 1-4.

(51) Jacob, D. J. Heterogeneous chemistry and tropospheric ozone. Atmos. Environ. 2000, 34, 2131-2159.

(52) Ellis, R. A.; Jacob, D. J.; Payer, M.; Zhang, L.; Holmes, C. D.; Schichtel, B. A.; Blett, T.; Porter, E.; Pardo, L. H.; Lynch, J. A. Present and Future Nitrogen Deposition to National Parks in the United States: Critical Load Exceedances. Atmos. Chem. Phys. Discuss. 2013, submitted.

(53) Clarke, J.; Edgerton, E.; Martin, B. Dry deposition calculations for the clean air status and trends network. Atmos. Environ. 1997, 31, 3667-3678.

(54) Logan, J. A.; Megretskaia, I.; Nassar, R.; Murray, L. T.; Zhang, L.; Bowman, K. W.; Worden, H. M.; Luo, M. Effects of the $2006 \mathrm{El}$ Nino on tropospheric composition as revealed by data from the Tropospheric Emission Spectrometer (TES). Geophys. Res. Lett. 2008, 35, L03816

(55) Henze, D. K.; Seinfeld, J. H.; Shindell, D. T. Inverse modeling and mapping US air quality influences of inorganic $\mathrm{PM}_{2.5}$ precursor emissions using the adjoint of GEOS-Chem. Atmos. Chem. Phys. 2009, 9, 5877-5903.

(56) Kopacz, M.; Mauzerall, D. L.; Wang, J.; Leibensperger, E. M.; Henze, D. K.; Singh, K. Origin and radiative forcing of black carbon transported to the Himalayas and Tibetan Plateau. Atmos. Chem. Phys. 2011, 11, 2837-2852.

(57) Lü, C.; Tian, H. Spatial and temporal patterns of nitrogen deposition in China: Synthesis of observational data. J. Geophys. Res. 2007, 112

(58) Vitousek, P. M.; Walker, L. R.; Whiteaker, L. D.; Matson, P. A. Nutrient limitations to plant growth during primary succession in Hawaii Volcanoes National Park. Biogeochemistry 1993, 23, 197-215, DOI: $10.1007 /$ BF00023752.

(59) Moxim, W. J. Simulated Transport of $\mathrm{NO}_{y}$ to Hawaii During August: A Synoptic Study. J. Geophys. Res. 1990, 95, 5717-5729.

(60) Jacob, D.; Horowitz, L.; Munger, J.; Heikes, B.; Dickerson, R.; Artz, R.; Keene, W. Seasonal transition from $\mathrm{NO}_{x}$-to hydrocarbonlimited conditions for ozone production over the eastern United States in September. J. Geophys. Res. 1995, 100, 9315-9324.

(61) Dentener, F. J.; Crutzen, P. J. Reaction of $\mathrm{N}_{2} \mathrm{O}_{5}$ on Tropospheric Aerosols: Impact on the Global Distributions of $\mathrm{NO}_{x}$ $\mathrm{O}_{3}$, and OH. J. Geophys. Res. 1993, 98, 7149-7163.

(62) Mollner, A. K.; Valluvadasan, S.; Feng, L.; Sprague, M. K.; Okumura, M.; Milligan, D. B.; Bloss, W. J.; Sander, S. P.; Martien, P. T.; Harley, R. A.; McCoy, A. B.; Carter, W. P. L. Rate of Gas Phase Association of Hydroxyl Radical and Nitrogen Dioxide. Science 2010, 330, 646-649.

(63) Kleffmann, J.; Becker, K.; Wiesen, P. Heterogeneous $\mathrm{NO}_{2}$ conversion processes on acid surfaces: Possible atmospheric implications. Atmos. Environ. 1998, 32, 2721-2729.

(64) Cheung, J. L.; Li, Y. Q.; Boniface, J.; Shi, Q.; Davidovits, P.; Worsnop, D. R.; Jayne, J. T.; Kolb, C. E. Heterogeneous Interactions of $\mathrm{NO}_{2}$ with Aqueous Surfaces. J. Phys. Chem. A 2000, 104, 26552662.

(65) Kurtenbach, R.; Becker, K.; Gomes, J.; Kleffmann, J.; Lörzer, J.; Spittler, M.; Wiesen, P.; Ackermann, R.; Geyer, A.; Platt, U. Investigations of emissions and heterogeneous formation of HONO in a road traffic tunnel. Atmos. Environ. 2001, 35, 3385-3394.

(66) Finlayson-Pitts, B. J.; Wingen, L. M.; Sumner, A. L.; Syomin, D.; Ramazan, K. A. The heterogeneous hydrolysis of $\mathrm{NO}_{2}$ in laboratory systems and in outdoor and indoor atmospheres: An integrated mechanism. Phys. Chem. Chem. Phys. 2003, 5, 223-242.

(67) Elshorbany, Y. F.; Steil, B.; Brühl, C.; Lelieveld, J. Impact of HONO on global atmospheric chemistry calculated with an empirical parameterization in the EMAC model. Atmos. Chem. Phys. 2012, 12, 9977-10000.

(68) Heald, C. L.; Collett, J. L.; Lee, T.; Benedict, K. B.; Schwandner, F. M.; Li, Y.; Clarisse, L.; Hurtmans, D. R.; Van Damme, M.; Clerbaux, C.; Coheur, P.-F.; Pye, H. O. T. Atmospheric ammonia and particulate inorganic nitrogen over the United States. Atmos. Chem. Phys. 2012 12, 10295-10312.

(69) van Vuuren, D.; Edmonds, J.; Kainuma, M.; Riahi, K.; Thomson, A.; Hibbard, K.; Hurtt, G.; Kram, T.; Krey, V.; Lamarque, J.-F.; Masui, T.; Meinshausen, M.; Nakicenovic, N.; Smith, S.; Rose, S. The representative concentration pathways: An overview. Clim. Change 2011, 109, 5-31, DOI: 10.1007/s10584-011-0148-z.

(70) Kim, S. W.; Heckel, A.; McKeen, S. A.; Frost, G. J.; Hsie, E. Y.; Trainer, M. K.; Richter, A.; Burrows, J. P.; Peckham, S. E.; Grell, G. A. Satellite-observed U.S. power plant $\mathrm{NO}_{x}$ emission reductions and their impact on air quality. Geophys. Res. Lett. 2006, 33, L22812.

(71) van der A, R. J.; Eskes, H. J.; Boersma, K. F.; van Noije, T. P. C.; Van Roozendael, M.; De Smedt, I.; Peters, D. H. M. U.; Meijer, E. W. Trends, seasonal variability and dominant $\mathrm{NO}_{x}$ source derived from a ten year record of $\mathrm{NO}_{2}$ measured from space. J. Geophys. Res. 2008, $113, \mathrm{D} 04302$.

(72) Lamarque, J.-F.; Kyle, G.; Meinshausen, M.; Riahi, K.; Smith, S.; van Vuuren, D.; Conley, A.; Vitt, F. Global and regional evolution of short-lived radiatively-active gases and aerosols in the Representative Concentration Pathways. Clim. Change 2011, 109, 191-212, DOI: $10.1007 / \mathrm{s} 10584-011-0155-0$.

(73) Pardo, L. H.; et al. Effects of nitrogen deposition and empirical nitrogen critical loads for ecoregions of the United States. Ecol. Appl. 2011, 21, 3049-3082. 